\title{
IMPORTANCE OF BUSINESS SOLUTIONS BASED ON BLOCKCHAIN TECHNOLOGY
}

The aim of this study is to determine the essence of blockchain technology and its capabilities to be utilized in business operations. The paper discusses the importance of blockchain technology and practical possibilities of its application. Based on industry reports, statistics on investments of enterprises in blockchain technology and attitudes of their senior executives towards this technology, as well as the validity of its implementation, have been presented. In addition, the most important advantages of blockchain technology in relation to existing information technology (IT) systems have been specified. The article describes organizational barriers hindering investments in blockchain technology and its actual applications in companies. Performed analyses show that companies around the world are actively investing in blockchain technology. This technology has been found to be positively recognized in business by executives, however companies, while planning its implementation, face numerous barriers which mainly arise from a lack of legal regulations, and technical problems. On the other hand, blockchain technology can be used in many areas of company activities, especially in the supply chain.

Keywords: blockchain, distributed ledger technology, investments JEL Codes: G15, G20, G29

\section{Introduction}

The creation of a cryptocurrency system based on blockchain technology has become a revolutionary solution in many aspects of economic functioning. In practice, blockchain is a distributed and shared database, managed by a network of computers, which operates according to predetermined rules called the blockchain protocol. The name blockchain is derived from the method in which the data is organized. The distributed database in the form of a block chain contains the history of all transactions or changes verified and approved by each participant ${ }^{1}$.

Blockchain technology was originally used to introduce cryptocurrencies as a means of payment. The first practical implementation of the blockchain system was Bitcoin (BTC). The rules for the operation of the bitcoin network were published in 2008 by S. Nakamoto, providing an opportunity for a new perspective on payment settlements ${ }^{2}$. This concept operates at two definition levels. In a narrow sense, Bitcoin is a digital, i.e. virtual unit of value, based on the encryption mechanism to ensure authenticity. It has been the first cryptocurrency in history which appeared on the

${ }^{1}$ PIIT: Blockchain $w$ Polsce, Raport Polskiej Izby Informatyki i Komunikacji, 2018. Retrieved: https://www.raportblockchain.pl/ (access: 20.04.2020).

${ }^{2}$ S. Nakamoto: Bitcoin: A Peer-to-Peer Electronic Cash System, 2008. Retrieved: https://bitcoin.org/bitcoin.pdf (access: 14.11.2020). 
Internet and in the economy. A broad approach, on the other hand, allows to define Bitcoin as an extensive information technology (IT) system based on a global, decentralized computer network, enabling and archiving transactions of value transfers, i.e. payments between users ${ }^{3}$. However, despite a considerable popularity, cryptocurrencies have not been widely accepted as a means of payment, due to a lack of legal regulations, fear of new payment systems, lack of trust in virtual money or considerable volatility of cryptocurrency prices and related risks ${ }^{4}$. Due to the significant volatility of cryptocurrency prices, it is an easy target for speculators. The speculative nature of bitcoin has been confirmed, among others, by Baur et al. ${ }^{5}$ However, blockchain technology has been more often used in practice to carry out transfers or conclude intelligent contracts without the control of financial institutions and market regulators.

This technology has a large potential and is being implemented by a greater number of enterprises and institutions, which is important, especially in the context of innovation in the area of business models and processes. A study by VMware indicates that blockchain technology has been implemented by over $67 \%$ of American banks with assets exceeding USD 100 billion. Thanks to blockchain technology, banking transactions can be registered in the distributed ledger technology and are verified by many decentralized entities, which affects their security ${ }^{6}$.

\section{Material and methods}

The aim of this study is to determine the essence of blockchain technology and its capabilities to be utilized in the economy, especially in business operations. The article uses methods of analysis and synthesis of the source material (secondary literature data and expert panel, thematic studies), applying elements of statistical analysis and presenting the results by using a descriptive and comparative method. The issues related to the use of blockchain technology in business were discussed, including benefits and risks associated with the implementation of this technology. The main results of empirical research and conclusions were based on the report published by Deloitte ${ }^{7}$. The study was commissioned by Deloitte Consulting LLP and was conducted online between 26 March and 5 April, 2018. The respondents in the study were senior executives in large international companies, operating in various industries in seven countries, namely: Canada, China, France, Germany, Mexico, Great Britain and the United States. Companies with annual revenues of at least USD 50 million were the

${ }^{3}$ W. Michalczyk: Bariery rozwoju bitcoina jako nowej formy pieniądza międzynarodowego, EKONOMIA XXI WIEKU, ECONOMICS OF THE 21ST CENTURY, 1(17)/2018, p. 43.

${ }^{4}$ More information about cryptocurrencies is presented in the article by M. Wiśniewska, M. Wasilewski: Znaczenie $i$ wykorzystanie kryptowalut, [in:] Finanse w działalności gospodarczej - teoria i praktyka, (ed.) Wasilewski M., Mądra-Sawicka M., Wydawnictwo SGGW, Warszawa, 2019, p. 143-154.

${ }^{5}$ D. G. Baur, K. Hong, A., D. Lee: Bitcoin: Medium of Exchange or Speculative Assets?, Accepted Manuscript, Journal of International Financial Markets, Institutions \& Money, $2017 . \quad$ Retrieved: https://www.researchgate.net/publication/321988034_Bitcoin_Medium_of_Exchange_or_Speculative_Assets (access: 14.11.2020).

${ }^{6}$ Online survey carried out for VMware by the Source Media Research in June 2017.

${ }^{7}$ Deloitte: Breaking blockchain open. Deloitte's 2018 global blockchain survey, 2018. Retrieved: https://www2.deloitte.com/uk/en/pages/innovation/articles/global-blockchain-survey-2018.html (access: 26.04.2020). 
subject of the study. The survey conducted by Deloitte involved 1053 senior executives with certain knowledge on the distributed ledger technology.

Moreover, selected results of the research conducted by PricewaterhouseCoopers on the use of distributed ledger technology, including blockchain technology, were also utilized in the present study. For this purpose, 600 managers from the largest companies with revenues above USD 1 billion were examined in 15 regions of the world ${ }^{8}$.

The article presented the data concerning company planned investments in blockchain technology and the respondents' attitude towards this technology and its implementation. In addition, the advantages and importance of the discussed technology in organizations as well as its practical application were depicted.

\section{The essence and application of blockchain technology}

Blockchain technology, called also distributed ledger technology (DLT), on which cryptocurrency is based, consists in the accumulation and storage of data transactions. This technology functions based on a block chain and the so-called distributed ledger, due to which blocks of subsequent transactions are attached to the previous ones to form a chain, and the payment is recorded simultaneously on all computers in the network ${ }^{9}$. In contrast to a transaction with a trusted third party which certifies each change in ownership every single time and stores the current data ledger, blockchain technology provides data on transactions for every user in a particular network. The basic distinguishing feature of this technology, compared to other distributed databases, is the consistent and reliable authentication of each transaction (by changing ownership rights) between anonymous users, who are driven by different motivations and do not need to trust each other ${ }^{10}$.

Blockchain technology is used in various areas of the economy, such as banking, finance, the business sector, medicine, public services, security or authentication systems ${ }^{11}$. Banks see their chances of implementing blockchain technology and related benefits in payments, contracts, applications, updating clients' data and processing their identification $^{12}$. One of the applications of this technology concerns the realization of contractual obligations, which involves the conclusion of so-called smart contracts. In the literature, smart contracts are also referred to as computer programs which can make decisions when certain conditions are met ${ }^{13}$.They consist of defining and fulfilling

\footnotetext{
${ }^{8}$ PriceWaterhouseCoopers $\quad(\mathrm{PwC})$ Global Blockchain Survey, 2018, Retrieved: https://www.pwc.com/gx/en/issues/blockchain/blockchain-in-business.html (access: 14.11.2020).

${ }^{9}$ W. Michalczyk: Bariery rozwoju bitcoina jako nowej formy pieniądza międzynarodowego, EKONOMIA XXI WIEKU, ECONOMICS OF THE 21ST CENTURY, 1(17)/2018, p. 43.

${ }^{10}$ M. Zaleska (ed.), Świat bankowości, Difin, Warszawa, 2009, p. 294.

${ }^{11}$ More information about blockchain technology, including application areas, is presented in the article by M. Wiśniewska: Istota $i$ możliwości wykorzystania technologii blockchain $w$ gospodarce, [in:] Strategie interesariuszy na rynku finansowym, (ed.) M. Wasilewski, S. Zabolotnyy, Wydawnictwo SGGW, Warszawa, 2019, p. 103-116.

${ }^{12}$ D. Zimnoch: Wptyw technologii blockchain na efektywność banku, Studia Ekonomiczne. Zeszyty Naukowe Uniwersytetu Ekonomicznego w Katowicach, Uniwersytet Ekonomiczny w Katowicach, 281/2016, p. 228.

${ }^{13}$ M. Kõlvart: Smart Contracts, [in:] The Future of Law and eTechnologies, (ed.) T. Kerikmäe, A. Rull, Springer, 2016, p. 134.
} 
the conditions contained in the contract in an automatic way, without third parties ${ }^{14}$. The most important feature of a smart contract is to secure the interests of both parties of the transaction in case one of them fails to fulfill their obligations ${ }^{15}$. According to a study of the International Monetary Fund, the use of smart contracts is associated with numerous benefits, such as increased efficiency, elimination of potential misappropriations, lowering of the costs of contract implementation and verification, or certainty that the contract will be performed as agreed by the parties ${ }^{16}$.

The potential of blockchain technology is also noticed in the context of the Internet of Things (IoT). The Internet of Things is the connection of devices to the network in such a way as to enable them to decentrally communicate with each other. This concept is based on constant technological progress and is associated with the existence of a global network connecting many devices and sensors that can exchange information independently. The application in this area may, among others, reduce the risk of attacks by decreasing the number of potential break-in sites ${ }^{17}$. Moreover, solutions based on blockchain technology can be used in the process of verification of entities, the purpose of which is to detect and prevent market manipulations, including money laundering. Due to the distributed ledger technology, it is also possible to create one database containing all available information about a given client. This database is automatically updated when a new document is made available by one of the users and consists of distributed replicas owned by all system participants. Payment systems, especially international, are another area of using blockchain technology. In the case of payment, the process of data consolidation required for the approval of the transaction is extended, due to the need to compare the records that are in possession by all the entities involved in transactions. Blockchain technology, through its decentralized and distributed character, allows each participant to analyze records and check the correctness of their transaction details ${ }^{18}$.

The usefulness and advantages of blockchain technology are the subject of research and observations; and ready implementations appear in most sectors of the economy. The analyses to date show significant opportunities for increasing the efficacy and streamlining of transaction systems, processes of asset tracking and auditing, as well as data management. From a technological point of view, blockchain development is very dynamic ${ }^{19}$. However, besides the advantages of the distributed ledger technology, its shortcomings can be also observed. This technology creates great development

\footnotetext{
14 M. Hulicki, P. Lustofin: Wykorzystanie technologii blockchain $w$ realizacji zobowiazań umownych, Człowiek w cyberprzestrzeni, 1/2017, p. 43.

${ }^{15}$ A. Żuwała A.: Możliwości wykorzystania technologii blockchain, Studies \& Proceedings of Polish Association for Knowledge Management, 87/2018, p. 64.

${ }^{16}$ IMF (International Monetary Fund), 2016: Virtual Currencies and Beyond: Initial Considerations, 01.2016, IMF Staff Discussion Note 16/03, International Monetary Fund, Washington, DC.

${ }^{17}$ A. Rot: Zastosowanie technologii Blockchain w kontekście bezpieczeństwa rozwiazań Internetu rzeczy, [in:] Wspomaganie zarządzania z wykorzystaniem technologii IT, Wydawnictwo Politechniki Częstochowskiej, 2017, p. 59, 68.

${ }^{18}$ K. M. Ciupa: Technologia blockchain i jej wptyw na rozwój infrastruktury rynku kapitałowego, [in:] Rynek kapitałowy - regulacje i fundamenty, (ed.) T. Czerwińska, A. Z. Nowak, Wydawnictwo Naukowe Wydziału Zarządzania Uniwersytetu Warszawskiego, Warszawa, 2018, p. 106-108.

${ }^{19}$ PIIT: Blockchain $w$ Polsce, Raport Polskiej Izby Informatyki i Komunikacji, 2018. Retrieved: https://www.raportblockchain.pl/ (access: 20.04.2020).
} 
opportunities, but also risks associated with its use. The selected benefits as well as risks arising from the implementation of blockchain technology are presented in Table 1.

Blockchain technology has a chance to become a revolutionary solution, especially owing to much lower operating costs compared to other systems and significant efficiency resulting from the lack of transaction-mediating institutions ${ }^{20}$. At the same time, the literature emphasizes that an important advantage of blockchain is the decentralization of various types of databases. Thanks to the transparency of these records, people who are users of the blockchain system have full insight into the transaction history. This technology gives the possibility of direct cooperation between foreign companies by eliminating the intermediary institutions, which has become a breakthrough solution ${ }^{21}$.

Table 1. Selected benefits and risks arising from the implementation of blockchain technology

\begin{tabular}{|c|c|}
\hline Benefits & Risks \\
\hline 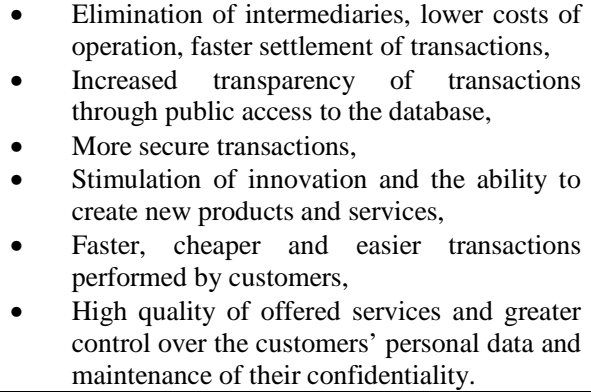 & $\begin{array}{l}\text { - Problems associated with technology } \\
\text { implementation, } \\
\text { No clear legal regulations regarding } \\
\text { transactions in the blockchain network, } \\
\text { - } \quad \text { Risk of hackers' attacks and phishing, } \\
\text { - Complicated interface, } \\
\text { - } \quad \text { Difficulties in settling cryptocurrencies and } \\
\text { valuing them in financial reports. }\end{array}$ \\
\hline
\end{tabular}

Skurce: Author's own analysis based on D. Zimnoch: Wptyw technologii blockchain na efektywność banku, Studia Ekonomiczne. Zeszyty Naukowe Uniwersytetu Ekonomicznego w Katowicach, Uniwersytet Ekonomiczny w Katowicach, 281/2016, p. 227-228; P. Międlar: Blockchain $w$ systemie finansowym, Studia i Prace Kolegium Zarządzania i Finansów, Oficyna Wydawnicza SGH, Warszawa, 173/2019, p. 84.

Elimination of time-consuming clearing and settlement procedures, which register changes in ownership and transfer money through central institutions, is very important in the functioning of blockchain technology. On the cryptocurrency market, the use of blockchain technology allows to obtain long-lasting stability of the payment system and transaction security for anonymous participants, with a significant reduction in transaction $\operatorname{costs}^{22}$. However, besides a number of facilities, blockchain technology brings many risks, including illegal exploitation. Moreover, the literature indicates numerous barriers related to the implementation of blockchain technology, such as regulations or problems with the adaptation of the solution among society ${ }^{23}$. Omitting

${ }^{20}$ M. Muszyński: Blockchain, czyli jak technologia Bitcoina robi karierę, 2016, Forbes, 1.08.2016. Retrieved: https://www.forbes.pl/technologie/blockchain-technologia-bitcoina-rewolucja-wcyberbezpieczenstwie/7z71ncj (access: 15.04.2020).

${ }^{21}$ M. Hulicki, P. Lustofin: Wykorzystanie technologii blockchain $w$ realizacji zobowiazań umownych, Człowiek w cyberprzestrzeni, 1/2017, p. 36 .

${ }^{22}$ E. Ślązak: Innowacyjność Blockchain jako rozproszonego rejestru danych (DTL), Prace Naukowe Uniwersytetu Ekonomicznego we Wrocławiu, Polityka ekonomiczna, 527/2018, p. 255.

${ }^{23}$ D. Zimnoch: Wptyw technologii blockchain na efektywność banku, Studia Ekonomiczne. Zeszyty Naukowe Uniwersytetu Ekonomicznego w Katowicach, Uniwersytet Ekonomiczny w Katowicach, 281/2016, p. 230-231 . 
intermediaries and the unknown role of regulators questions the essence of using blockchain technology in the financial system. Security of this technology is also questioned, and the risk of hackers' attacks or phishing becomes a real threat. Furthermore, blockchain technology is also characterized by a complicated interface and non-intuitive work environment, which hinders mass usability and application. Accounting practitioners, in turn, notice problems in cryptocurrency settlement when making transactions, and see difficulties related to the valuation of cryptocurrencies in financial reports ${ }^{24}$. However, the literature emphasizes the fact that the benefits of using blockchain, such as cost reduction, outweigh the shortcomings, which motivates banks and other institutions to look for solutions eliminating obstacles in its development and implementation $^{25}$. Additionally, the advantages of blockchain technology facilitate doing business in the digital world. Despite the shortcomings and risks this technology can generate, it creates huge opportunities for further development and wide use in economic and social life ${ }^{26}$.

\section{Results of empirical research and discussion}

Distributed ledger technology (DLT) has been gaining popularity in recent years and more and more global organizations are implementing it. Deloitte, an international consulting company in auditing, accounting, and strategic and operational management, conducted a study on the direction of development and practical application of blockchain technology. Over 1000 senior executives and directors from major companies in Canada, China, Great Britain and the United States were examined. Figure 1 shows the results concerning planned investments in blockchain technology in 2018 or 2019.

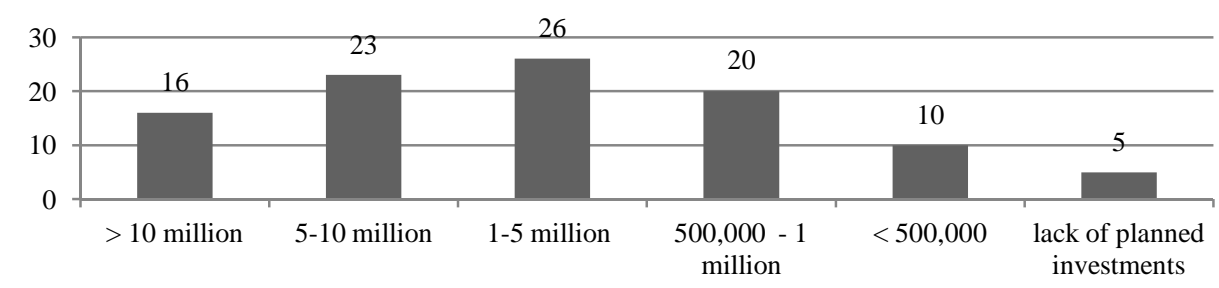

Figure 1. The percentage of respondents declaring investments in blockchain technology as a function of investment value [in USD]

Source: Author's own analysis on the basis of Deloitte's Report: Breaking blockchain open. Deloitte's 2018 Global Blockchain Survey, 2018, p. 18.

The survey shows that this technology is a priority investment for many companies. About $60 \%$ of respondents indicate that their organization will invest at least USD 1 million in blockchain technology in the year in which the survey was conducted or in

${ }^{24}$ P. Międlar: Blockchain w systemie finansowym, Studia i Prace Kolegium Zarządzania i Finansów, Oficyna Wydawnicza SGH, Warszawa, 173/2019, p. 84.

${ }^{25}$ D. Zimnoch: Wpływ technologii blockchain na efektywność banku, Studia Ekonomiczne. Zeszyty Naukowe Uniwersytetu Ekonomicznego w Katowicach, Uniwersytet Ekonomiczny w Katowicach, 281/2016, p. 231.

${ }^{26}$ R. Boniecki, J. Rawłuszko: Możliwości wykorzystania technologii Blockchain w biznesie, Ekonomiczne Problemy Usług, 1/2017 (126), t.2, p. 12-13. 
the following year, and approximately $40 \%$ of respondents will invest at least USD 5 million. Most of the answers given concern planned investments in the amount of USD 1-5 million (26\%), while the lack of planned investments is confirmed by only $5 \%$ of respondents.

Company senior executives are optimistic about the potential of blockchain technology. Table 2 presents the respondents' attitude to this technology and its implementation. The most positive responses $(84 \%)$ concerned the ability to broadly scale and the possibility of widespread use of blockchain technology. This state of affairs can be confirmed by the results of research conducted by PricewaterhouseCoopers, which show that companies operating in global markets were actively involved in the technology of distributed ledgers. Most of the surveyed managers (84\%) confirmed that the companies they represented were at least primarily involved in blockchain technology at the stage of their development, research or practical use.

Table 2. The respondents' attitude to blockchain technology and its implementation

\begin{tabular}{|l|c|}
\hline \multicolumn{1}{|c|}{ Specification } & $\begin{array}{c}\text { Compliance with } \\
\text { individual statements } \\
(\%)\end{array}$ \\
\hline 1. Blockchain technology is broadly scalable and will find widespread application \\
\hline $\begin{array}{l}\text { 2. Suppliers/clients/competitors discuss or work on blockchain solutions, to meet } \\
\text { the challenges of technology }\end{array}$ & 74 \\
\hline $\begin{array}{l}\text { 3. There are business premises for the use of blockchain technology (in the opinion } \\
\text { of your management team) }\end{array}$ & 74 \\
\hline $\begin{array}{l}\text { 4. It is planned to replace the current record systems with technology based on } \\
\text { blockchain }\end{array}$ & 69 \\
\hline $\begin{array}{l}\text { 5. Your company will lose a competitive advantage, if you do not apply blockchain } \\
\text { technology }\end{array}$ & 68 \\
\hline $\begin{array}{l}\text { 6. Blockchain technology will introduce disturbances in the industry which the } \\
\text { managers represent }\end{array}$ & 59 \\
\hline 7. Blockchain technology is overhyped & 59 \\
\hline
\end{tabular}

Source: Author's own analysis on the basis of Deloitte's Report: Breaking blockchain open. Deloitte's 2018 Global Blockchain Survey, 2018, p. 19.

The Deloitte survey shows that over $70 \%$ of respondents confirmed ongoing work on technology solutions and indicated existing business premises regarding its use. More than half of the respondents planned to replace conventional accounting systems with blockchain technology $(69 \%)$ and stated that there was a possibility of losing competitive advantage by enterprises in case they do not apply the distributed ledger technology. Most company executives also agreed that blockchain technology would disrupt industries which they represent ${ }^{28}$. Despite positive expectations connected with block-chain technology, around $40 \%$ of respondents stated that this technology

\footnotetext{
${ }^{27}$ The percentage of respondents who agreed with particular statements; the sum of percentages is over $100 \%$ because the respondents could choose more than one answer.

${ }^{28}$ The Deloitte study shows that blockchain technology can cause the greatest number of distortions in the automotive industry, as well as in sectors related to biotechnology and pharmacy, oil and gas, which was confirmed by over $70 \%$ of respondents, while the least distortions are observed in the public sector $(46 \%$ of responses).
} 
is overhyped. This means that even blockchain supporters are aware that some issues regarding the potential of this technology are too optimistic.

Blockchain technology is mainly described in the literature from the perspective of its numerous advantages and applications. Figure 2 presents the advantages of blockchain technology in comparison to existing IT systems, according to the opinions of global company executives. The most frequent answer to the question about the strengths of blockchain technology concerned its speed - every third respondent on average mentioned such an advantage. This means that the companies are interested in using blockchain technology to exchange information in real time in order to accelerate business processes and thus to increase operational efficiency.

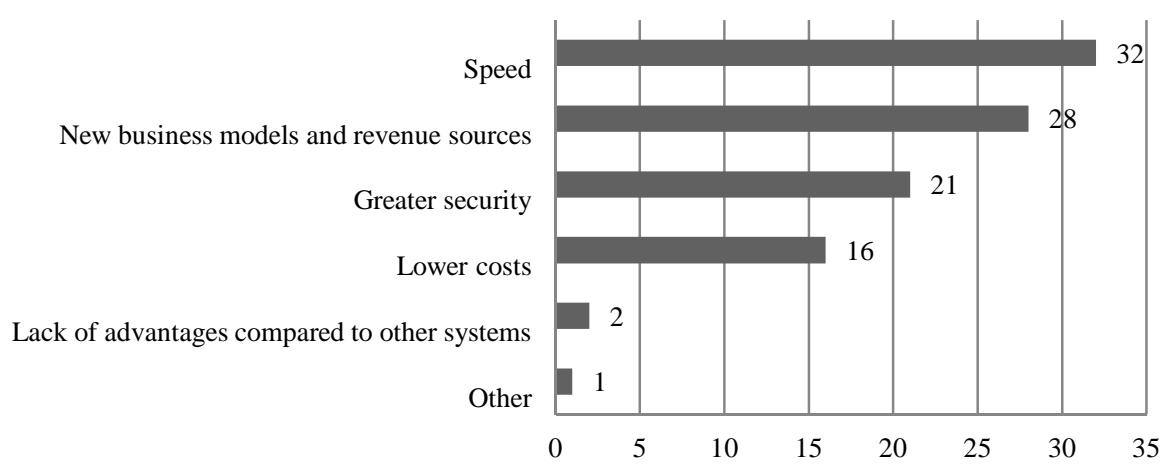

Figure 2. Respondents' opinion on the advantages of blockchain technology over existing systems (\%) Source: Author's own analysis on the basis of Deloitte's Report: Breaking blockchain open. Deloitte's 2018 Global Blockchain Survey, 2018, p. 21.

In addition, around $30 \%$ of respondents believe that this technology can be helpful in creating new business models, creating additional sources of revenue for the company. On average, every fifth respondent considered greater security ${ }^{29}$ and lower risk as an advantage, while $16 \%$ of responses were related to lower costs as compared to the existing system solutions.

\footnotetext{
${ }^{29}$ Over $80 \%$ of respondents considered this technology as more reliable compared to conventional IT systems, and only less than $10 \%$ of respondents had a different opinion on this subject.
} 


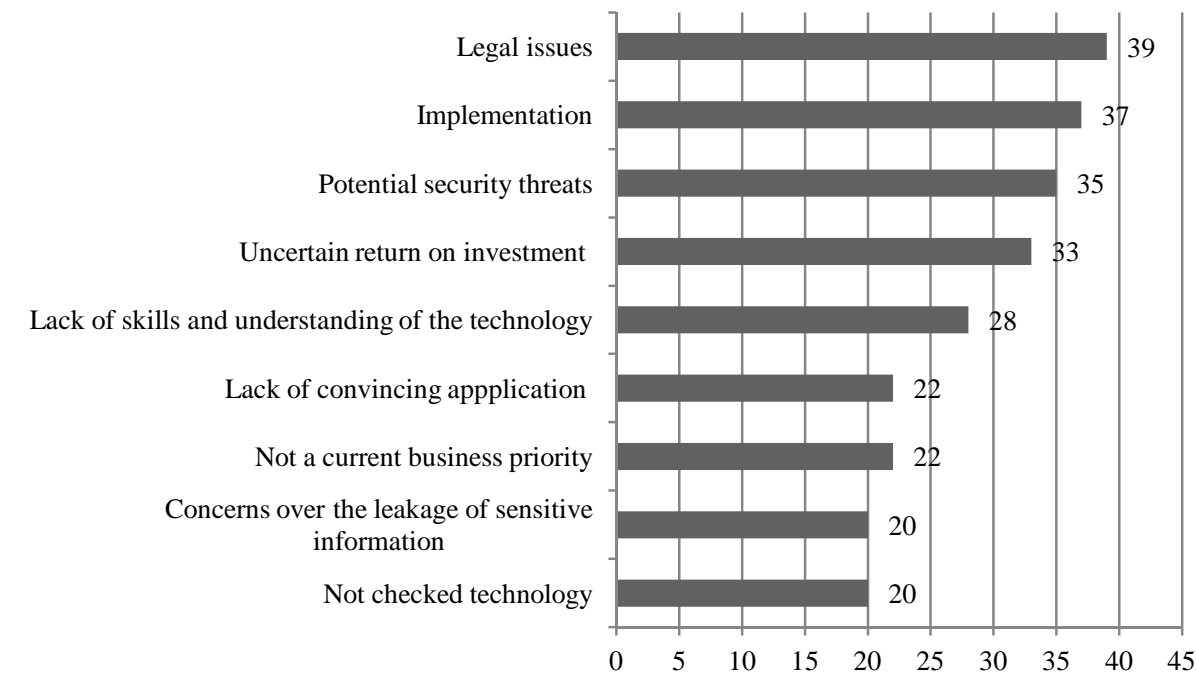

Figure 3. Respondents' opinion on barriers in companies hindering investment in blockchain technology (\%) Source: Author's own analysis on the basis of Deloitte's Report: Breaking blockchain open. Deloitte's 2018 Global Blockchain Survey, 2018, p. 24.

Despite the significant costs which are planned to be invested in blockchain technology, companies intending to implement it face numerous barriers (Figure 3.). Legal issues (39\%), technical problems related to the implementation of this technology, i.e. its replacement or adaptation to the older system (37\%) and potential security threats $(35 \%)$ are most often identified as barriers which limit further investment in this area. Moreover, frequently provided responses were about the uncertain return on investment (ROI) (33\%) and lack of understanding of blockchain technology (28\%). Another survey on blockchain technology conducted by PricewaterhouseCoopers shows that it is not clear for society what this blockchain really is and what the possibilities of its use are in the economy. The distributed ledger technology is not easy to explain, and in addition, gaps in legal regulations foster a lack of confidence in blockchain technology. Although most regulatory bodies accept this technology, the regulatory environment in this area is still unresolved ${ }^{30}$.

${ }^{30}$ More information on this subject in: G. Sobiecki: Regulowanie kryptowalut $w$ Polsce $i$ na świecie na przykładzie bitcoina: status prawny i interpretacja ekonomiczna, Problemy Zarządzania 13/3 (1), 2015 p. 148160. 


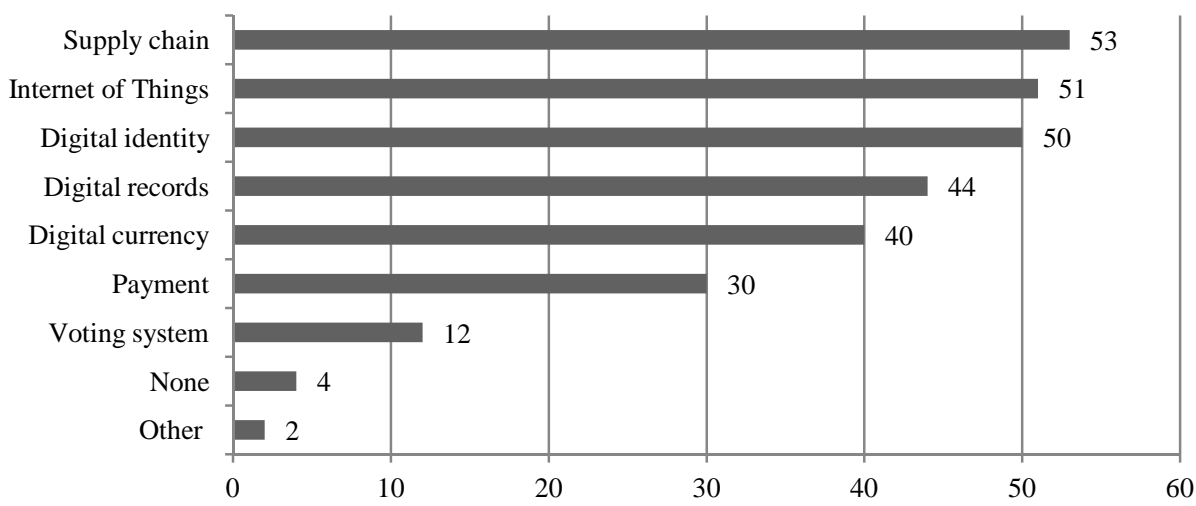

Figure 4. Respondents' opinion on the use of blockchain technology in organizations (\%)

Source: Author's own analysis on the basis of Deloitte's Report: Breaking blockchain open. Deloitte's 2018 Global Blockchain Survey, 2018, p. 29.

Figure 4 shows the applications of blockchain technology in organizations. Over half of the responses of company senior executives pointed to the use of technology in the supply chain and in the Internet of Things. Other frequently provided responses concerned digital records (44\%), digital currencies $(40 \%)$ and payment system $(30 \%)$.

The literature on this research subject indicates that the use of blockchain technology in the supply chain can contribute to eliminating areas that are characterized by lack of effectiveness, and improving operational processes at many levels of company operations, from the production and processing stage, to logistics and accounting. The potential impact of blockchain technology on future practices and principles of supply chain operation was investigated, among others, by Wang Y. et al. ${ }^{31}$. The authors identified key factors of technology development in the supply chain and indicated the latest applications of this technology.

Blockchain technology can accelerate and facilitate many logistic processes, equipping them with a common source of information, thus ensuring a new level of transparency and security in the supply chain ${ }^{32}$. Since distributed ledger technologies are resistant to manipulation, they can contribute to reducing the number of frauds and increasing transparency at every point in the supply chain ${ }^{33}$.

Similarly, the use of blockchain technology in the context of the Internet of Things can have numerous advantages for companies. At the same time, A. Rot and R. Zygała emphasize that the dynamic development of the Internet of Things market brings with it many challenges, especially related to security, and blockchain may be the solution to

${ }^{31}$ Y. Wang, J. H. Han, P. Beynon-Davies: Understanding blockchain technology for future supply chains: a systematic literature review and research agenda. Supply Chain Management, An International Journal, 24, 1, 2019, p. 62-84.

32 M. Wodnicka: Technologie blockchain przyszłościa logistyki, Zeszyty Naukowe Małopolskiej Wyższej Szkoły Ekonomicznej w Tarnowie, 1(41), 2019, p. 43.

33 P. Szewczyk: Application of blockchain technology in supply chain management, Zeszyty Naukowe Organizacja i Zarządzanie, Wydawnictwo Politechniki Sląskiej, 136, 2019, p. 591. 
some of these problems ${ }^{34}$. On the other hand, the use of blockchain technology related to the Internet of Things can help companies to reduce the risk of attacks, by reducing the number of potential break-in sites ${ }^{35}$.

\section{Conclusions}

The analyses on the nature of blockchain technology and possibility of its use in economic practice and business allow to draw the following conclusions:

1. Global companies actively invest in blockchain technology and are actively involved in the distributed ledger technology at the stage of the development, research or practical use.

2. Blockchain technology is positively perceived by senior executives of global companies. Among the numerous advantages of technology based on blockchain, the speed and security are most often listed, as compared to conventional IT systems.

3. Companies planning to implement blockchain technology face numerous barriers. Uncertain legal regulations and technical issues related to its implementation, as well as a lack of understanding of this technology due to the system complexity pose a significant challenge to company executives.

4. Blockchain technology can be used in many areas of business operations. Particular importance in the business applications of this technology can be attributed to the supply chain and the Internet of Things.

\section{References}

Baur D. G., Hong K., Lee A. D.: Bitcoin: Medium of Exchange or Speculative Assets?, Accepted Manuscript, Journal of International Financial Markets, Institutions \& Money, 2017.Retrieved:https://www.researchgate.net/publication/321988034_Bitcoin_Medium_of_Excha nge_or_Speculative_Assets (access: 14.11.2020).

Boniecki R., Rawłuszko J.: Możliwości wykorzystania technologii Blockchain $w$ biznesie, Ekonomiczne Problemy Usług, 1/2017 (126).

Ciupa K. M.: Technologia blockchain i jej wptyw na rozwój infrastruktury rynku kapitałowego, [in:] Rynek kapitałowy - regulacje i fundamenty, (ed.) Czerwińska T., Nowak A. Z., Wydawnictwo Naukowe Wydziału Zarządzania Uniwersytetu Warszawskiego, Warszawa, 2018. Deloitte: Breaking blockchain open. Deloitte's 2018 global blockchain survey, 2018. Retrieved: https://www2.deloitte.com/uk/en/pages/innovation/articles/global-blockchain-survey-2018.html (access: 26.04.2020).

EPRS (European Parliamentary Research Service), Delivorias A., 2016: Distributed Ledger Technology and Financial Markets, November. Retrieved: http://www.europarl.europa.eu/RegData/etudes/BRIE/2016/593565/EPRS_BRI(2016)593565_EN. pdf (access: 14.11.2020).

Hulicki M., Lustofin P.: Wykorzystanie technologii blockchain $w$ realizacji zobowiąań umownych, Człowiek w cyberprzestrzeni, 1/2017.

${ }^{34}$ A. Rot, R. Zygała: Technologia blockchain jako rewolucja $w$ transakcjach cyfrowych. Aspekty technologiczne i potencjalne zastosowania, Informatyka ekonomiczna 4(50), 2018, p. 131.

${ }^{35}$ More information on this subject in: A. Rot: Zastosowanie technologii Blockchain w kontekście bezpieczeństwa rozwiazań Internetu rzeczy, [in:] Wspomaganie zarządzania z wykorzystaniem technologii IT, Wydawnictwo Politechniki Częstochowskiej, 2017, p. 57-71. 
IMF (International Monetary Fund): Virtual Currencies and Beyond: Initial Considerations, 01.2016, IMF Staff Discussion Note 16/03, International Monetary Fund, Washington, DC, 2016. Kõlvart M.: Smart Contracts, [in:] The Future of Law and eTechnologies, (ed.) Kerikmäe T, Rull A., Springer, 2016.

Michalczyk W.: Bariery rozwoju bitcoina jako nowej formy pieniądza międzynarodowego, EKONOMIA XXI WIEKU, ECONOMICS OF THE 21ST CENTURY, 1(17)/2018.

Międlar P.: Blockchain w systemie finansowym, Studia i Prace Kolegium Zarządzania i Finansów, Oficyna Wydawnicza SGH, Warszawa, 173/2019.

Muszyński M.: Blockchain, czyli jak technologia Bitcoina robi kariere, 2016, Forbes, 1.08.2016. Retrieved: https://www.forbes.pl/technologie/blockchain-technologia-bitcoina-rewolucja-wcyberbezpieczenstwie/7z71ncj (access: 15.04.2020).

Nakamoto S.: Bitcoin: A Peer-to-Peer Electronic Cash System, 2008. Retrieved: https://bitcoin.org/bitcoin.pdf (access: 14.11.2020).

PIIT: Blockchain w Polsce, Raport Polskiej Izby Informatyki i Komunikacji, 2018. Retrieved: https://www.raportblockchain.pl/ (access: 20.04.2020).

PriceWaterhouseCoopers (PwC): Global Blockchain Survey, 2018. Retrieved: https://www.pwc.com/gx/en/issues/blockchain/blockchain-in-business.html (access: 14.11.2020).

Rot A.: Zastosowanie technologii Blockchain w kontekście bezpieczeństwa rozwiazań Internetu rzeczy, [in:] Wspomaganie zarządzania z wykorzystaniem technologii IT, Wydawnictwo Politechniki Częstochowskiej, 2017.

Rot A., Zygała R.: Technologia blockchain jako rewolucja $w$ transakcjach cyfrowych. Aspekty technologiczne i potencjalne zastosowania, Informatyka ekonomiczna 4 (50), 2018.

Sobiecki G.: Regulowanie kryptowalut $w$ Polsce $i$ na świecie na przyktadzie bitcoina: status prawny i interpretacja ekonomiczna, Problemy Zarządzania 13/3 (1), 2015.

Ślązak E.: Innowacyjność Blockchain jako rozproszonego rejestru danych (DTL), Prace Naukowe Uniwersytetu Ekonomicznego we Wrocławiu, Polityka ekonomiczna, 527/2018.

Szewczyk P: Application of blockchain technology in supply chain management, Zeszyty Naukowe Organizacja i Zarządzanie, Wydawnictwo Politechniki Śląskiej 136, 591, 2019.

Wiśniewska M., Wasilewski M.: Znaczenie $i$ wykorzystanie kryptowalut, [in:] Finanse w działalności gospodarczej - teoria i praktyka, (ed.) Wasilewski M., Mądra-Sawicka M., Wydawnictwo SGGW, Warszawa, 2019.

Wiśniewska M.: Istota i możliwości wykorzystania technologii blockchain w gospodarce, [in:] Strategie interesariuszy na rynku finansowym, (ed.) Wasilewski M., Zabolotnyy S., Wydawnictwo SGGW, Warszawa, 2019.

Wang, Y., Han, J.H., and Beynon-Davies, P.: Understanding blockchain technology for future supply chains: a systematic literature review and research agenda. Supply Chain Management, An International Journal, 24, 1, 2019.

Wodnicka M.: Technologie blockchain przyszłościa logistyki, Zeszyty Naukowe Małopolskiej Wyższej Szkoły Ekonomicznej w Tarnowie, 1(41), 2019.

VMware: Press release, 2017. Retrieved: https://www.vmware.com/pl/company/news/releases/2017/vmware-survey-the-banking-sector-isleading-in-the-implementation-110717.html. Access: 14.11.2019.

Zaleska M. (ed.): Świat bankowości, Difin, Warszawa, 2019.

Zimnoch D.: Wptyw technologii blockchain na efektywność banku, Studia Ekonomiczne, Zeszyty Naukowe Uniwersytetu Ekonomicznego w Katowicach, Uniwersytet Ekonomiczny w Katowicach, 281/2016.

Żuwała A.: Możliwości wykorzystania technologii blockchain, Studies \& Proceedings of Polish Association for Knowledge Management, 87/2018. 


\section{Znaczenie rozwiązań opartych na technologii blockchain w biznesie}

\section{Streszczenie}

Celem opracowania jest określenie istoty technologii blockchain oraz możliwości jej wykorzystania w działalności przedsiębiorstw. W opracowaniu omówiono znaczenie technologii blockchain i możliwości praktycznego jej zastosowania. Opierając się o raporty branżowe przedstawiono statystyki dotyczące inwestycji dokonywanych $\mathrm{w}$ przedsiębiorstwach w technologię blockchain, jak również stosunku kadry kierowniczej spółek do tej technologii oraz zasadności jej wdrażania. Sprecyzowano ponadto najważniejsze zalety technologii blockchain w stosunku do istniejących systemów informatycznych. Wskazano bariery organizacyjne, utrudniające inwestycje $\mathrm{w}$ tę technologię oraz wykorzystywane w spółkach rzeczywiste jej zastosowania. Z przeprowadzonych analiz wynika, że spółki na świecie aktywnie inwestują w technologię blockchain. Stwierdzono, że technologia ta jest pozytywnie postrzegana w biznesie przez zarządzających, jednak spółki planując ją wdrożyć napotykają na liczne bariery, które w dużej mierze wynikają z braku uregulowań prawnych, jak również problemów technicznych związanych z implementacją. Jednocześnie technologia blockchain może być wykorzystywana w wielu obszarach działalności przedsiębiorstw, zwłaszcza w łańcuchu dostaw.

Słowa kluczowe: blockchain, technologia rozproszonych rejestrów, inwestycje JEL Codes: G15, G20, G29

\section{$\underline{\text { Information about author }}$}

Marta Wiśniewska, PhD

Jan Kochanowski University in Kielce, Branch in Piotrków Trybunalski

114/118 Słowackiego St., 97-300 Piotrków Trybunalski

email: marta.wisniewska@ujk.edu.pl

ORCID: 0000-0001-5500-316X 